IJIS Indonesian Journal on Information System

\title{
IMPLEMENTASI SISTEM E-LEARNING MENGGUNAKAN SOFTWARE MOODLE PADA POLITEKNIK SAINS DAN TEKNOLOGI WIRATAMA MALUKU UTARA
}

\section{IMPLEMENTATION OF E-LEARNING SYSTEM USING THE SOFTWARE MOODLE IN POLYTECHNIC OF SCIENCE AND TECHNOLOGY WIRATAMA NORTH MALUKU}

\author{
Arisandy Ambarita \\ Program Studi Manajemen Informatika, \\ Politeknik Sains dan Teknologi Wiratama Maluku Utara \\ arisandy.ambarita@gmail.com
}

\begin{abstract}
Abstrak
E-Learning merupakan kependekan electronic learning adalah sebuah proses pembelajaran dimana penyampaian materi, diskusi, ujian dan lain-lain yang berkaitan dengan kegiatan perkuliahan dilakukan melalui media elektronik. Politeknik Sains dan Teknologi Wiratama merupakan salah satu perguruan tinggi swasta yang bergerak dalam bidang Teknologi Informasi. Sistem pembelajaran yang ada di Politeknik Sains dan Teknologi Wiratama pertemuan secara tatap muka. Sistem belajar tatap muka mempunyai kelemahan yakni jika dosen tidak hadir maka belajar mengajar menjadi terhambat begitupun dengan mahasiswa yang berhalangan hadir maka akan ketinggalan pelajaran dan kurang memahami materi yang dibahas pada saat mahasiswa yang bersangkutan tidak hadir. penelitian ini bertujuan untuk mengimplementasikan sistem E-Learning model pembelajaran mata kuliah secara online dengan menggunakan software moodle yang bersifat open source dan gratis. Software Moodle dipilih sebagai software yang mendukung model pembelajaran mata kuliah secara online dan memiliki kelengkapan modul dan fasilitas serta mudah diterapkan. Dengan adanya sistem ini memudahkan dosen dalam penyampaian materi dan melakukan evaluasi saat dosen tersebut berhalangan hadir dan memberikan kemudahan bagi Mahasiswa dan Dosen untuk dapat saling berinteraksi kapan dan dimana saja dalam meningkatkan kualitas belajar Mahasiswa
\end{abstract}

\section{Kata Kunci : Sistem, E-Learning, Moodle}

\begin{abstract}
E-Learning is short for electronic learning is a learning process in which the delivery of content, discussion, examination, and other related learning activities conducted through electronic media. Wiratama Polytechnic Science and Technology is one of the private universities are engaged in the field of Information Technology. The system of learning in Science and Technology Polytechnic wiratama meeting face to face. To-face learning system has the drawback that if the lecturer is not present then learning to be blocked as well as with students who are unable to attend will miss class and do not understand the material covered during the student does not attend. This research aims to implement the E-Learning system learning model of online courses using Moodle software that is open source and free. Software Moodle selected as the software that supports the learning model of online courses and has a complete module and facilities as well as easy to implement. With this system
\end{abstract}


facilitates a lecturer in the delivery of materials and evaluated when the lecturer is unable to attend and provide facilities for students and lecturers to be able to interact with each other anytime and anywhere in improving the quality of student learning

Keyword: System, E-Learning, Moodle

\section{PENDAHULUAN}

Pengintegrasian Teknologi Informasi dan Komunikasi ke dalam proses pembelajaran dapat meningkatkan Informa-tion Communication and Technology literacy, membangun karateristik masyarakat ber-basis pengetahuan (knowledge-based society) pada diri siswa, di samping dapat meningkatkan efektifitas dan efisiensi proses pembelajaran itu sendiri. Dalam mengintegrasikan TIK ke dalam proses pembelajaran, Fryer dalam Romi Satria Wahono (2007, pp.226-246) menyarankan dua pendekatan yang dapat dilakukan guru ketika merencanakan pembelajaran yang mengintegrasikan TIK, yaitu: (1) pendekatan topik (theme centered approach); dan (2) pen-dekatan software (software-centered approach

E-Learning merupakan kependekan electronic learning (Sohn,2005), salah satu definisi umum E-learning yang berikan Gilbert\&Jhones (2001) yaitu : pengiriman materi pembelajaran melalui satu media elektronik seperti internet, intranet/extranet, Satelite broadcast, Audio/video tape, interactive TV, CD-rom dan Computer-Based Training (CBT), defenisis yang hampir sama di usulkan juga oleh the Australian National Training Authority (2003) yakni meliput Aplikasi dan proses yang menggunakan media elektronik seperti internet, intranet/extranet, Satelite broadcast, Audio/video tape, interactive TV dan CDrom guna mengirimkan materi pembelajaran secara fleksibel.
Moodle adalah software open source yang mendukung implementasi e-learning dengan paradigma terpadu dimana fiturfitur moodle yang dipakai untuk menunjang pembelajaran seperti tugas, kuis, komuni-kasi, kolaborasi dan mengupload materi pembelajaran dapat dengan mudah dapat diakomodasikan dalam suatu portal e-learning (Surjono, 2010, pp.5-6).

Mengkombinasikan antara pertemuan secara tatap muka dengan pembelajaran elektronik dapat meningkatkan kontribusi dan interaktifitas antar peserta didik. Melalui tatap muka peserta didik dapat mengenal sesama pesertadidik dan guru pendampingnya. Keakraban ini sangat menunjang kerja kolaborasi mereka secara virtual. Persiapan matang sebelum mengimplementasikan sebuah pembelajaran berbasis multimedia memegang peran penting demi kelancaran proses pembelajaran. Segala persiapan seperti penjadwalan sampai dengan penentuan teknis komunikasi selama proses pembelajaran merupakan tahapan penting dalam melaksanakan pembelajaran berbasis web. seperti halnya pada Politeknik Sains dan Teknologi Wiratama

Politeknik Sains dan Teknologi Wiratama merupakan salah satu perguruan tinggi swasta yang bergerak dalam bidang Teknologi Informasi. Sistem pembelajaran yang ada di Politeknik Sains dan Teknologi Wiratama pertemuan secara tatap muka. Sistem belajar tatap muka mempunyai kelemahan yakni jika dosen tidak hadir maka belajar mengajar menjadi terhambat begitupun dengan mahasiswa yang berhalangan hadir maka akan 
ketinggalan pelajaran dan kurang memahami materi yang dibahas pada saat mahasiswa yang bersangkutan tidak hadir.

Dengan melihat masalah yang di hadapi oleh Politeknik Sains dan Teknologi Wiratama Maluku Utara, peneliti mencoba mengimplementasikan sistem E-Learning model pembelajaran mata kuliah secara online dengan menggunakan software moodle yang bersifat open source dan gratis. Software Moodle dipilih sebagai software yang mendukung model pembelajaran mata kuliah secara online dan memiliki kelengkapan modul dan fasilitas serta mudah diterapkan. melalui tatap muka dan pembelajaran online dengan e-Learning akan membentuk sistem pembelajaran eLearning yang menggabungkan antara sistem pembelajaran konvensional melalui tatap muka dan sistem pembelajaran kelas virtual melalui e-Learning. Dengan adanya inovasi pembelajaran secara online dan tatap muka ini diharapkan dapat meningkatkan kualitas belajar Mahasiswa

\section{Rumusan Masalah}

Berdasarkan latar belakang masalah yang telah dikemukakan di atas, maka ditetapkan rumusan masalah, yaitu: "Bagaimana mengimplementasikan Sistem E-Learning sebagai media belajar mahasiswa dengan menggunakan Software Moodle" penelitian ini di batasi, yaitu Sistem yang di implementasikan pada mata kuliah Pengantar Microprocessor, dan penilaian quiz soal latihan essay bersifat manual, Sistem yang dikembangkan hanya membantu perkuliahan tatap muka pada Politeknik Sains dan Teknologi Wiratama, bukan pengganti perkuliahan tatap muka,sehingga dapat Memberikan kemudahan bagi Mahasiswa dan Dosen untuk dapat saling beriteraksi kapan dan dimana saja, dalam penyampaian materi dan melakukan evaluasi saat dosen tersebut berhalangan hadir

\section{LANDASAN TEORI Definisi E-Learning}

Istilah e-Learning mengandung pengertian yang sangat luas, sehingga banyak pakar yang menguraikan tentang definisi e-Learning dari berbagai sudut pandang. Salah satu definisi yang cukup dapat diterima banyak pihak misalnya dari Darin E. Hartley yang menyatakan eLearning merupakan suatu jenis belajar mengajar yang memungkinkan tersampaikannya bahan ajar ke siswa dengan menggunakan media Internet, Intranet atau media jaringan komputer lain. LearnFrame.Com dalam Glossary of e-Learning Terms menyatakan suatu definisi yang lebih luas bahwa e-Learning adalah sistem pendidikan yang menggunakan aplikasi elektronik untuk mendukung belajar mengajar dengan media Internet, jaringan komputer,maupun komputer standalone. Dari puluhan atau bahkan ratusan definisi yang muncul dapat kita simpulkan bahwa sistem atau konsep pendidikan yang memanfaatkan teknologi informasi dalam proses belajar mengajar dapat disebut sebagai suatu e-Learning.

Dari beberapa sistem $e$-Learning yang ada, secara umum dapat dibagi berdasarkan sifat interaktivitasnya dan dapat dibedakan kedalam dua kelompok yaitu e-Learning statis dan e-Learning dinamis. Sistem e-Learning dikatakan bersifat statis jika antara pengguna sistem tidak dapat saling berinteraksi, pembelajar hanya dapat men-download bahan-bahan yang diperlukan dan admin hanya dapat meng-upload file-file materi. Sistem ini 
biasanya digunakan hanya sebagai penunjang aktifitas belajar-mengajar yang dilakukan secara tatap muka dikelas. Sedangkan sistem e-Learning dapat digolongkan kedalam e-Learning yang bersifat dinamis apabila siswa mampu belajar dengan dalam lingkungan yang tidak jauh berbeda dengan suasana kelas dimana di dalam sistem ini terdapat kemungkinan untuk berinteraksi antara pembelajar dan tutornya baik melalui email, chatting maupun sarana komunikasi lainnya. (Suteja dan Harjoko, 2008).

\section{MOODLE}

Moodle adalah merupakan salah satu paket software untuk membuat suatu pelatihan - pelatihan berbasis web dan internet yang biasa disebut sebagai Learning Management System (LMS) / Course Management System (CMS) / Virtual Learning Environment (VLE). Moodle disediakan secara gratis dan bebas digunakan karena merupakan software open source (dibawah lisensi GNU Public).

\section{Pengguna Moodle ( LMS )}

Dalam manajemen Moodle masing masing pengguna memiliki tugas dan kewenangan yaitu :

\section{Admin}

a. Website diatur oleh Admin, yang telah ditetapkan ketika membuat website.

b. Tampilan (Themes) diizinkan pada Admin untuk memilih warna, jenis huruf, susunan dan lain sebagainya untuk kebutuhan tampilan.

c. Bentuk kegiatan yang ada dapat ditambah

d. Source Code yang digunakan ditulis dengan menggunakan PHP.
Mudah untuk dimodifikasi dan sesuai dengan kebutuhan.

\section{Dosen}

a. Dosen mengendalikan secara penuh untuk mengatur kuliah, termasuk melarang pengajar yang lain

b. Memilih bentuk/metode kuliah seperti berdasarkan mingguan, berdasarkan topik atau bentuk diskusi

c. Terdapat Materi. Forum, ujian/quiz, Tugas, yang digunakan untuk mendukung proses belajar.

d. Bahan kuliah dapat dipaketkan dengan menggunakan file zip

e. Dosen mempunyai hak istimewa, sehingga dapat mengubah (memodifikasi) bahan kuliah

\section{Mahasiswa}

a. Metode Email standar : Mahasiswa dapat membuat nama pemakai untuk login. Alamat email akan diperiksa melalui konfirmasi.

b. Semua Pengguna dapat membuat biografi sendiri, serta menambahkan photo.

c. Tiap orang disarankan cukup pengguna saja untuk seluruh sever. Tiap pengguna dapat mempunyai akses yang berbeda

d. Tamu dan mahasiswa bisa mendownload materi kuliah yang telah di buat oleh dosen pada bagan mingguan.

\section{Proses Perkuliahan Pada Moodle}

\section{Mekanisme Menggunakan Moodle}

Untuk menggunakan Moodle. Para pengguna harus terlebih dahulu melakukan pendaftaran agar dapat memanfaatkan fasilitas di E-Learning Politeknik Sains dan Teknologi Wiratama, pada proses pendaftaran para penguna harus mempunyai alamat email. Alamat email diperlukan untuk mengkonfirmasi 
kebenaran alamat email yang digunakan. Oleh sebab itu, setelah mendaftar, untuk masuk yang pertama kali ke Moodle harus melalui link yang telah dikirimkan melalui email ketika mendaftar.

a. Username adalah nama user yang telah didaftarkan oleh Administrator User ke dalam sistem hak aksesnya

b. Password adalah kata kunci yang dimiliki oleh masing-masing user dan hanya diketahui oleh user yang bersangkutan untuk masuk ke dalam sistem menggunakan username tersebut. Dengan demikian, orang lain tidak bisa masuk ke dalam sistem dengan menggunakan username tertentu kecuali mengetahui passwordnya

\section{Mekanisme Perkuliahan pada Bagan Mingguan}

Untuk mengakses perkuliahan perminggu pada Moodle para Mahasiswa atau peserta harus terlebih dahulu melakukan pendaftaran agar dapat memanfaatkan fasilitas dan materi - materi pada perkuliahan di E-Learning Politeknik Sains dan Teknologi Wiratamayang telah di sediakan oleh dosen pembimbing mata kuliah tersebut. Mahasiswa atau peserta dapat memilih salah satu mata kuliah yang akan di ikuti pada perkuliahan tersebut. Pada tampilan mata kuliah terdapat bagan mingguan yang akan di gunakan oleh mahasiswa atau peserta kuliah.

Untuk mengikuti proses perkuliahan mahasiswa atau peserta harus terdaftar pada mata kuliah tersebut. Untuk penilaian kehadiaran akan terlaksanakan secara ototmatis apabila peserta atau Mahasiswa tersebut aktif mengikuti dan mendownload materi - materi yang telah di tentukan oleh dosen, apabila materi tersebut dalam bentuk file pdf, doc, ppt dan lain - lain. serta tugas - tugas yang telah di sediakan oleh dosen pada akhir kuliah

Pada minggu berikut dosen akan melaksanakan sebuah uijian/quiz pada moodle untuk dapat mengetahui prestasi dari mahasiswa atau peserta yang mengikuti mata kuliah tersebut

Kegiatan ini merupakan bagian dari proses belajar-mengajar perminggu pada moodle, sehingga kehadiran mahasiswa atau peserta harus dilihat berdasarkan aktifitas mahasiswa atau peserta melalui login ke sistem eLearning (pengganti absent di kelas)

\section{Mekanisme Diskusi atau Forum}

Forum diskusi online dapat digunakan sebagai sarana diskusi mahasiswa-dosen maupun mahasiswamahasiswa. Forum ini juga dapat digunakan untuk menyampaikan pengumuman menambah topic dan membalas pesan.

Agar dapat mengakses forum dari suatu kuliah, terlebih dulu peserta atau mahasiswa harus dapat mengakses kuliah tersebut Pada Diskusi/Forum pengajar dapat menambahkan forum ke kuliah. Forum dapat juga ditambahkan ke halaman depan (homepage) E-Learning oleh admin. Saat membuat forum, pengajar akan mengisi deskripsi dari forum itu. Pengajar bebas menguraikan deskripsi tentang forum. Deskripsi ini pertama kali akan dilihat oleh mahasiswa yang memasuki forum tersebut.

Mengirim pesan di forum itu mudah. Fasilitas pengedit teks yang mirip MS Word di dalam program penjelajah sudah tersedia. Lewat pengaturan tertentu, di forum mahasiswa dapat mengunggah berkas. Dengan demikian dimungkinkan membuat skenario kerja sama tugas kelompok antar mahasiswa lewat forum. 
Forum dapat juga dipakai untuk mendiskusikan tugas yang pengajar berikan kepada mahasiswa.

\section{$4 \quad$ Mekanisme ujian atau Quiz}

Kategori Bank Soal pada course homepage dengan LMS Moodle pada setiap sistem Moodle adalah 'default'. Kategori ini dapat memudahkan dosen dalam menyajikan soal-soal tersebut kepada peserta kuliah. Adapun jenis-jenis soal yang siap digunakan antara lain : essay, mencocokkan, jawaban tempelan (close), pilihan ganda, isian, benar-salah dan lain - lain Soal-soal dengan jawaban bisa menjadi sumber bahan ajar yang menunjang peserta dalam mendapatkan pemahaman terhadap materi yang disampaikan oleh dosen kepada mahasiswa

Dosen membuat modul ujian/quiz . Setelah Dosen mengupload semua modul dan materi pada bagan mingguan, Dosen juga membuat quiz berbentuk pilihan ganda dan isian pada bagan mingguan. Dengan jumlah masing - masing soal, setiap mahasiswa yang mengikuti quiz/ujian tersebut akan mendapat. range skor untuk nilai quiz adalah dari 0 - 100.

Kegiatan quiz/ujian yang dilakukan offline adalah kegiatan tidak dilakukan melalui internet. Walaupun demikian, kegiatan ini dapat dimasukkan ke dalam Moodle sehingga nilainya terintegrasi dengan nilai - nilai kegiatan online. pembuatan kegiatan quis/ujian offline sama dengan pembuatan tugas. Perbedaanya adalah pada saat pembuatan jenis tugas di isi dengan kegiatan offline perbedaan yang lain adalah pada kegiatan offline tidak ada file yang di kirimkan oleh mahasiswa

\section{$5 \quad$ Mekanisme Penilaian}

Penilaian keseluruhan kegiatan pada moodle merupakan bagian dari keseluruhan nilai Akhir mahasiswa. Penilaian akan di berikan oleh dosen pada setiap mahasiswa atau peserta yang mengikuti kuliah online dan mempelajari bahan-bahan materi dengan mendownload materi tersebut, melaksanakan tugasnya, serta mengikuti quiz/ujian online yang diadakan, maka ia secara otomatis akan memperoleh nilai masing - masing yang telah ditetapkan oleh dosen yang bersangkutan

Penilaian jawaban mahasiswa pada Quiz/ujian dilakukan secara otomatis oleh sistem. Untuk pertanyaan - pertanyaan yang sangat terbuka dimana tidak mungkin dinilai oleh sistem, maka pengajar harus menilai jawaban secara manual atau offline. Berikut adalah metode penilaian kegiatan mahasiswa atau peserta pada moodle

Tabel 1: Metode penilaian pada Software Moodle

\begin{tabular}{|c|c|c|}
\hline Highest & Lower & Letters \\
\hline $100,00 \%$ & $85,00 \%$ & $\mathrm{~A}$ \\
\hline $84,99 \%$ & $70,00 \%$ & $\mathrm{~B}$ \\
\hline $69,99 \%$ & $55,00 \%$ & $\mathrm{C}$ \\
\hline $54,99 \%$ & $45,00 \%$ & $\mathrm{D}$ \\
\hline $44,99 \%$ & $39,00 \%$ & $\mathrm{E}$ \\
\hline
\end{tabular}

Nilai huruf secara umum terdiri atas abjad mulai dari A sebagai nilai tertinggi tiap nilai huruf memiliki rentan waktu tertentu, rentan nilai dalam hal ini adalah presentasi nilai yang di dapat nilai total yang mungkin di dapat misalnya rentan nilai 85 sampai 99 maksudnya adalah nilai yang di dapat adalah $85 \%$ sampai $99 \%$ dari 
nilai total yang mungkin di dapat. Mahasiswa yang presentase rentan nilai ini akan mendapat nilai huruf $\mathrm{A}$ demikian juga rentan yang lebih rendah akan di sesuaikan nilai hurufnya, dosen tersebut berhak merubah nilai persen ini sesuai kebutuhan

Pada moodle dosen yang bersangkutan juga dapat mengupload nilai sendiri dengan mengimport dari file CSV atau XML

\section{Defenisi Sistem Informasi}

Sistem informasi menurut Burch dan Strater (1974 ) dalam Moekijat (2005), adalah kumpulan bagian-bagian yang formal dan sistematis yang melaksanakan operasi pengolahan data untuk memenuhi persyaratan pengolahan data yang legal dan transaksional, memberikan informasi kepada manajemen untuk mendukung kegiatan - kegiatan perencanaan, pengendalian, dan pengambilan keputusan, serta memberikan bermacam-macam laporan seperti yang diperlukan pihak luar Tugas dari sistem informasi adalah untuk melakukan siklus pengolahan data. Untuk melakukan siklus ini, maka sebagai suatu sistem diperlukan komponenkomponen tertentu. Telah diketahui bahwa data perlu diolah untuk dijadikan informasi yang berguna lewat suatu siklus. Siklus ini disebut siklus pengolahan data atau disebut juga dengan nama siklus informasi (Jogiyanto, 2009).

\section{WAMP5 1.7.2}

WAMP adalah singakatan dari kombinasi Windows, Apache, MySQL dan PHP sebuah aplikasi yang dapat menjadikan komputer kita menjadi sebuah server. Karena dalam hal ini komputer yang akan kita pakai harus memberikan pelayanan untuk pengaksesan web, untuk itu komputer kita harus menjadi server, WAMP merupakan sebuah installer yang akan menginstall paket aplikasi yang terdiri dari Apache, MySQL, PHP, PHP myadmin, SQLitemanager, Wampserver service manager, secara bersamaan serta sekaligus mengkonfigurasinya sehingga dapat langsung digunakan.

WAMP menyediakan suatu lingkungan untuk mengembangkan aplikasi web programming yang bersifat server side, sehingga anda dapat menjalankan aplikasi yang dibuat dengan menggunakan bahasa pemorgraman PHP dan database MySQL, dengan server Apache, di atas sistem operasi Windows, secara lokal.WAMP dapat diperoleh secara gratis, selain itu proses instalasinya sangat mudah.

\section{Apache}

Pada awal mulanya, Apache merupakan perangkat lunak sumber terbuka yang menjadi alternatif dari server web Netscape (sekarang dikenal sebagai Sun Java System Web Server. Sejak April 1996 Apache menjadi server web terpopuler di internet. Pada Mei 1999, Apache digunakan di 57\% dari semua web server di dunia. Pada November 2005 persentase ini naik menjadi 71\%. (sumber: Netcraft We Server Survey, November 2005).

\section{MySQL}

MySQL merupakan software yang tergolong sebagai DBMS (Database Management Sistem) yang bersifat Open Source. Open Source menyatakan bahwa software ini dilengkapi dengan source code (kode yang dipakai untuk membuat MySQL), selain tentu saja bentuk executable-nya atau kode yang dapat dijalankan secara langsung dalam sistem 
operasi, dan bisa diperoleh dengan cara men-download (mengunduh) di Internet secara gratis (Kadir, 2008:2).

\section{PHP}

Nugroho (2008:113) Jika diartikan, sebenarnya PHP memiliki beberapa pandangan dalam mengartikannya, akan tetapi kurang lebih PHP dapat kita ambil arti sebagai PHP: Hypertext Preeprocesor. Ini merupakan bahasa yang hanya dapat berjalan pada server dan hasilnya dapat ditampilkan pada client. Saputra (2011:4344) PHP merupakan suatu bahasa pemograman yang berjalan pada sisi server (server side scripting). Jadi, PHP membutuhkan Web server untuk dapat menjalankannya.PHP menyatu dengan kode HTML (kita akan mempraktekkannya pada pembahasan selanjutnya) untuk membuat suatu web yang dinamis. PHP merupakan software bersifat open source (gratis) dan mampu lintas platform, yaitu dapat digunakan dengan sistem operasi dan web server apapun. PHP mampu berjalan di windows dan beberapa versi linux.

\section{Flowchart}

Flowchart adalah bagan-bagan yang mempunyai arus yang menggambarkan langkah-langkah penyelesaian suatu masalah. penggambaran secara grafik dari langkah-langkah dan urut-urutan prosedur dari suatu program. Flowchart menolong analis dan programmer untuk memecahkan masalah kedalam segmen-segmen yang lebih kecil dan menolong dalam menganalisis alternatif-alternatif lain dalam pengoperasian

\section{METODE PENELITIAN}

Menurut Sugiyono

pengumpulan data dalam penelitian dilakukan melalui tiga kegiatan, yaitu observasi, wawancara dan dokumentasi.

a. Observasi, yaitu penelitian langsung atau pengamatan ke objek penelitian untuk mengetahui secara langsung tentang masalah yang dihadapi.

b. Wawancara adalah proses pengumpulan data dengan cara tanya jawab langsung dengan Mahasiswa dan Staf pengajar pada Politeknik Sains dan Teknologi Wiratama Maluku Utara

c. Metode dokumentasi dalam penelitian ini dimaksudkan untuk memperoleh data berbentuk dokumentasi, berupa gambar, Brosur atau Majalah yang ada pada Politeknik Sains dan Teknologi Wiratama Maluku Utara

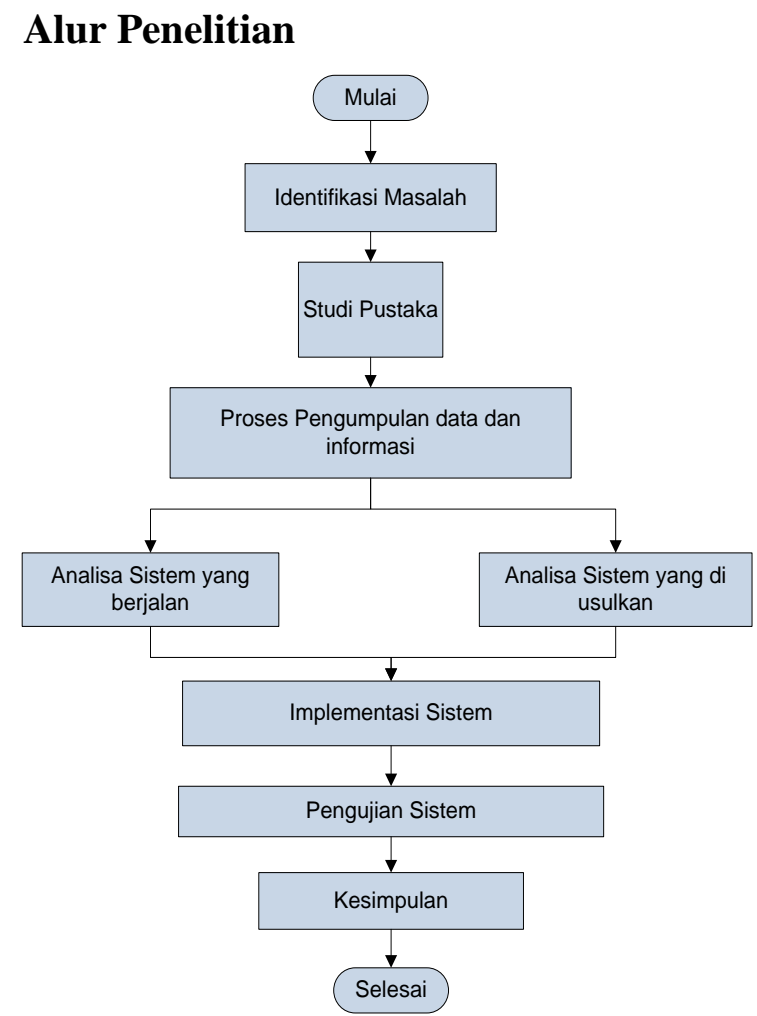

Gambar 1 : Alur Penelitian

\section{Analisa sistem yang berjalan}

Berikut adalah alur sistem yang berjalan di tampilkan pada pada Flowchart system dapat dilihat pada gambar berikut 


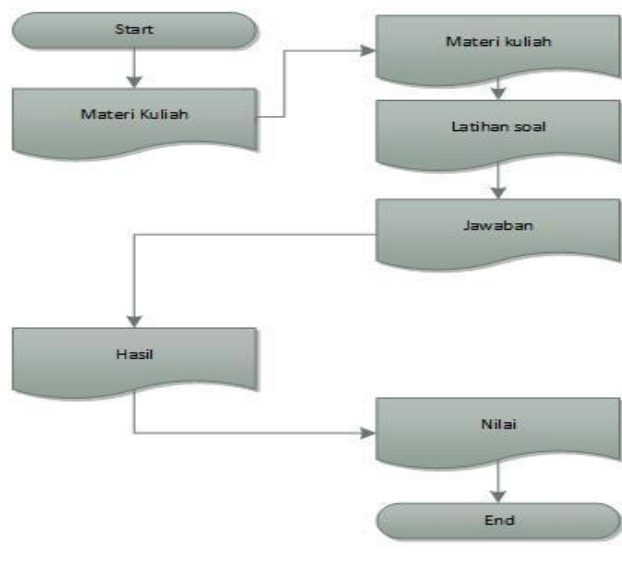

Gambar 2 : Flowchart Sistem Yang Berjalan

\section{Rancangan system yang di usulkan}

Rancangan Sistem yang di usulkan merupakan sistem yang baru untuk menunjang kegiatan belajar mengajar pada Politeknik Sains dan Teknologi Wiratama Maluku Utara Sebagai berikut:

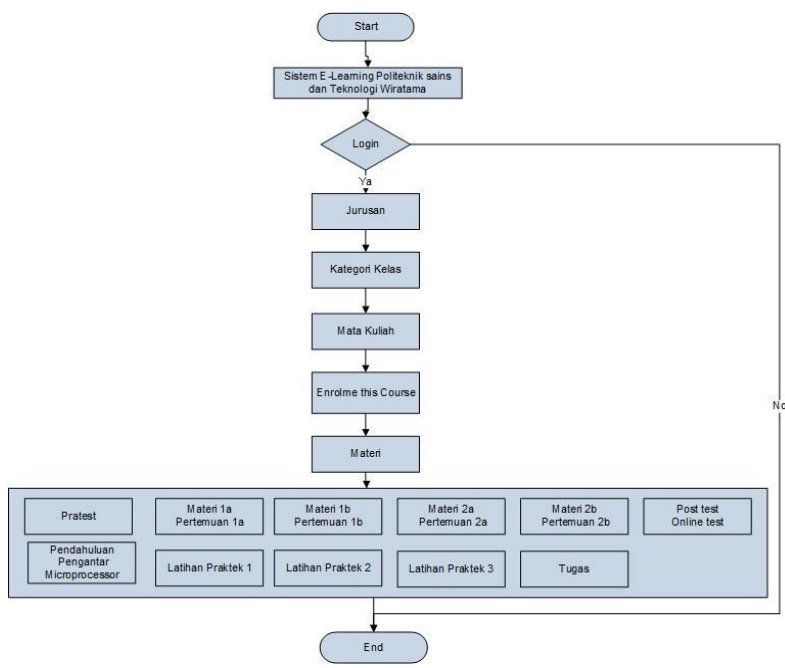

Gambar 3 : Flowchart Rancangan Sistem Yang Diusulkan

\section{Kebutuhan fungsional}

Kebutuhan fungsional adalah kebutuhan - kebutuhan yang memiliki keterkaitan langsung dengan sistem. Kebutuhan fungsional dari sistem ini meliputi
1. Kebutuhan user (Dosen dan Mahsiswa)

a. Mendapatkan Informasi Perkuliahan

b. Melihat Informasi pada Sistem Elearning

c. Berbagi Informasi dan beriteraksi pada system E-learning tentang materi perkuliahan

2. Kebutuhan administrator

a. Melakukan login ke system

b. Memanagement data Sistem ELearning

\section{Kebutuhan non-fungsional}

Kebutuhan non-fungsional adalah kebutuhan yang tidak secara langsung terkait dengan fitur tertentu di dalam sistem.

1. Kebutuhan perangkat keras

Notebook Acer Aspire 4752, dengan spesifikasi sebagai berikut:

a. Processor Intel Core i3-2330M.

b. Mainboard Intel.

c. Ram 2GB.

d. Hardisk 500 GB.

2. Kebutuhan perangkat lunak

Adapun perangkat lunak yang digunakan untuk membangun sistem ini adalah sebagai berikut

a. Sistem Operasi Windows 7 Ultimate

b. Moodle Sebagai media atau Aplikasi yang di gunakan dalam mengimplementasi E-learning

c. XAMPP 1.8.3 sebagai web server dan media database

d. Sublime text sebagai script editor.

e. Microsoft visio digunakan untuk menggambar desain system seperti flowchart

\section{IMPLEMENTASI SISTEM}


Menu Tampilan Interface Sistem ELearning Politeknik Sains dan Teknologi Wiratama

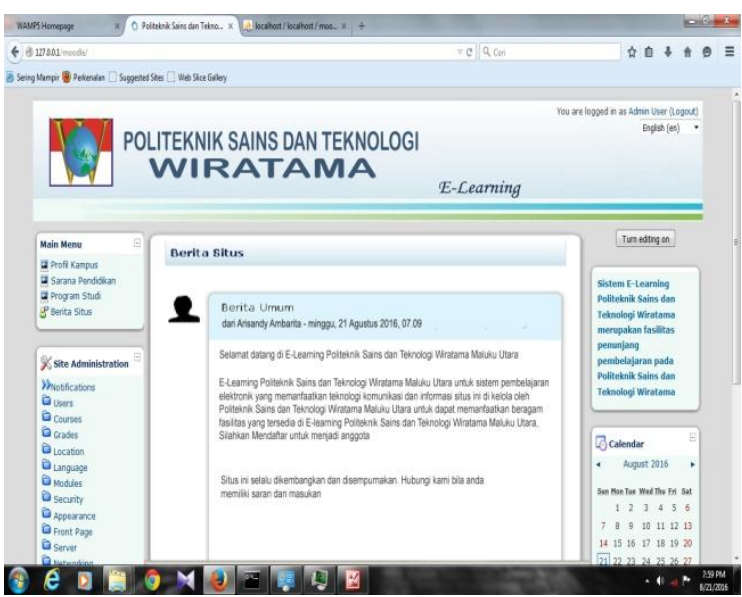

Gambar 4 : Interface Sistem E-Learning

\section{Tampilan Halaman Login E-Learning Politeknik Sains dan Teknologi} Wiratama

Pada halaman ini merupakan tampilan berita dan informasi, pengunjung dapat melihat berita dan informasi

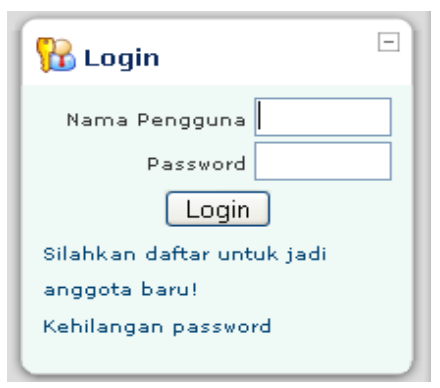

Gambar 5 : Menu Login

\section{Tampilan Menu Profil Dosen}

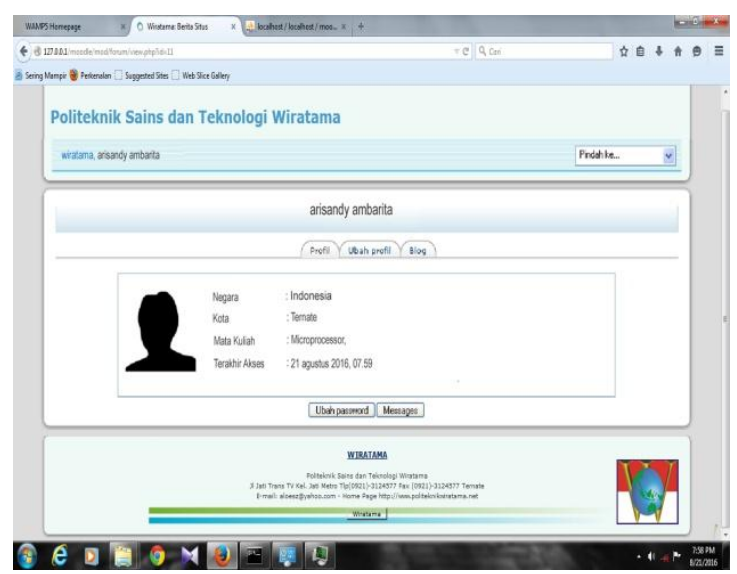

Gambar 6 : Menu Profil Dosen
Menu Perkuliahan Sistem E-Learning mata kuliah Pengantar Microprocessor

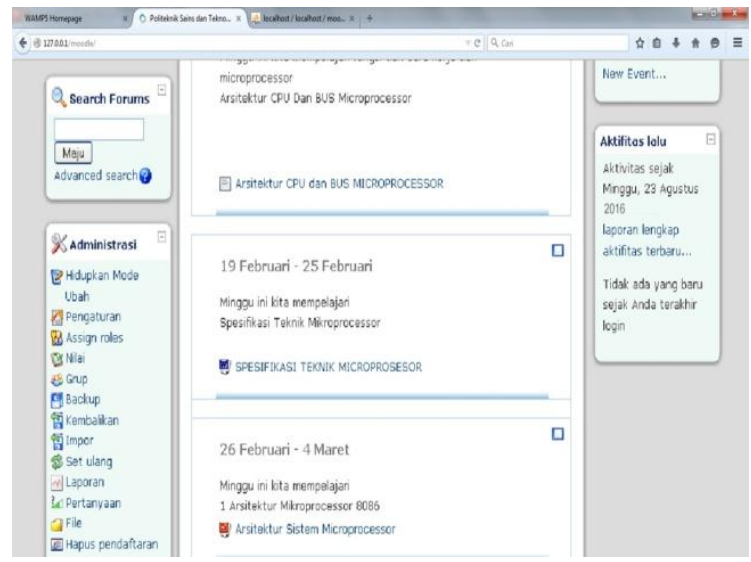

Gambar 7 : Menu Perkuliahan mata kuliah Pengantar Microprocessor

\section{Temapilan Menu laporan Perkuliahan}

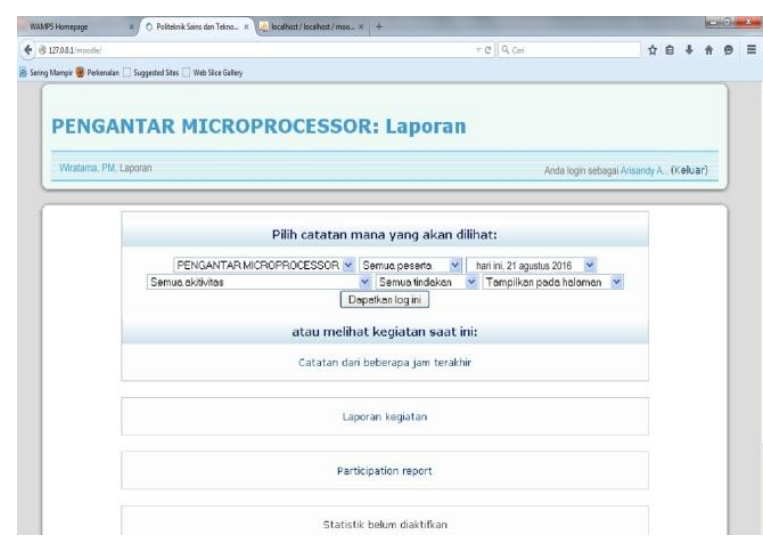

Gambar 8 : Menu Laporan Perkuliahan

\section{Tampilan Menu Menyelenggarakan Quiz}

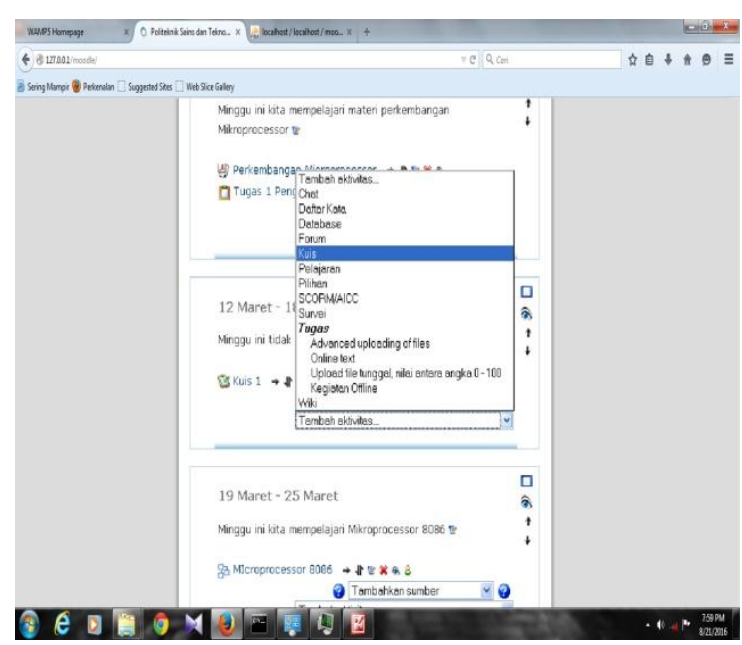

Gambar 9 : Menu Penyelenggaraan Quiz 


\section{Tampilan Menu Daftar Nilai}

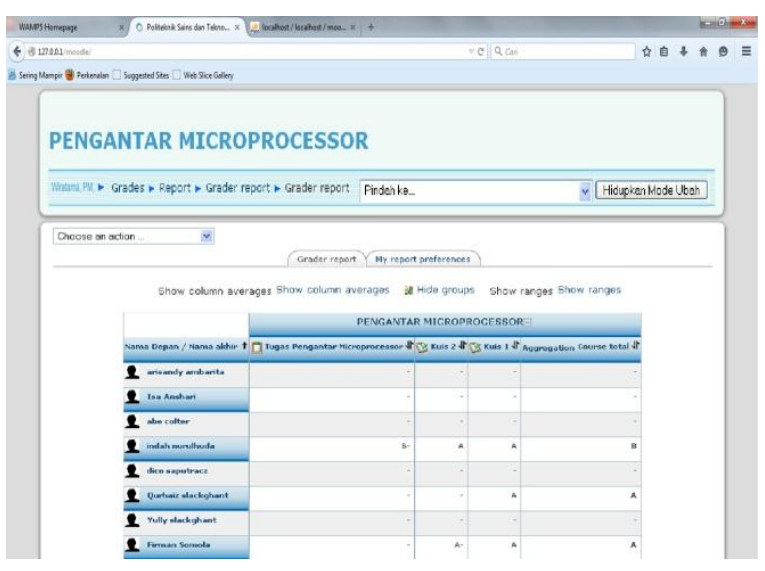

Gambar 10 : Menu Daftar Nilai

\section{Tampilan Menu Nilai Tugas}

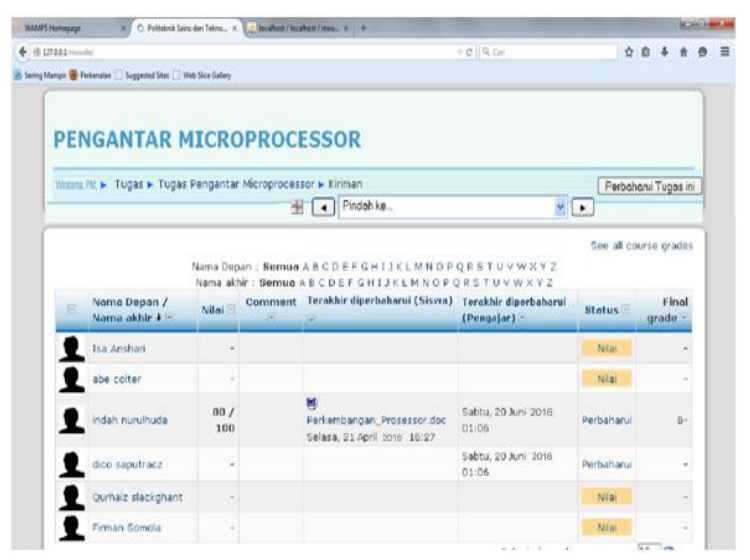

Gambar 11 : Menu Nilai Tugas penilaian tugas yang di kirim dari mahasiswa

\section{Tampilan Menu Konfigurasi Nilai Tugas yang di kirim}

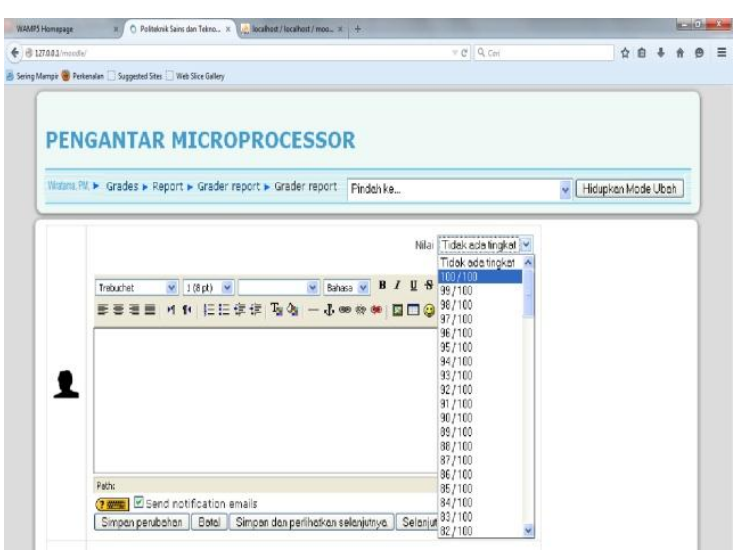

Gambar 12 : Menu Konfigurasi penilaian tugas yang di kirim dari mahasiswa

Tampilan Menu Konfigurasi Daftar Nilai Mahasiswa

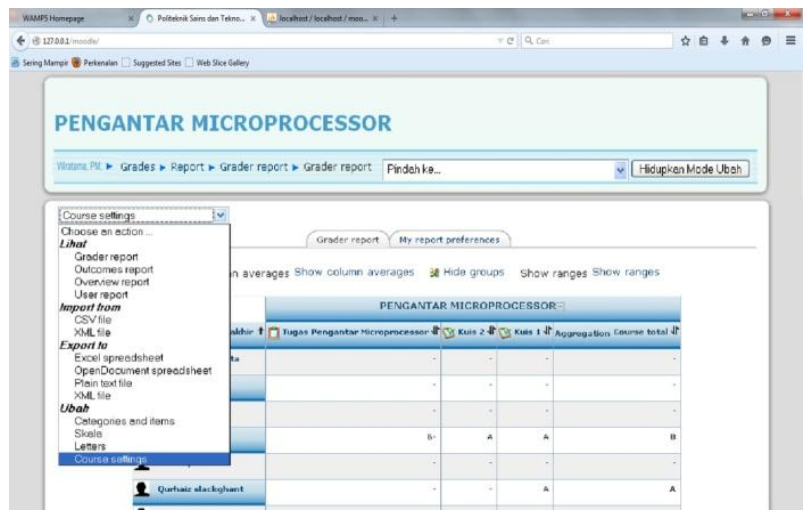

Gambar 13 Tampilan pilihan untuk mengkonfigurasi daftar nilai Mahasiswa

\section{KESIMPULAN}

Hasil Implementasi Sistem ELearning menggunakan Software Moodle pada Politeknik Sains dan Teknologi Wiratama di simpulkan sebagai berikut: 1) dapat membantu pelaksanaan proses belajar mengajar dan memberikan kemudahan dalam menunjang belajar mengajar dosen; 2) dapat mengatur pertemuan online sehingga proses belajar mengajar tanpa kendala jarak dan waktu, dapat dilakukan secara bersamaan atau jika dosen yang berhalangan hadir

Berdasarkan kesimpulan di atas, maka diajukan saran sebagai berikut.: 1) dapat menerapkan Sistem E-Learning untuk semua mata kuliah dengan mengunakan software Moodle untuk meningkatkan kulitas belajar mengajar pada Politeknik Sains dan Teknologi Wiratama Maluku Utara: 2) dapat di jadikan sebagai acuan untuk menciptakan suatu aliran formasi yang baru secara sistematis dan terintegrasi yang dapat di susun menjadi sebuah sistem yang terpadu

\section{DAFTAR PUSTAKA}


Kadir, Abdul. 2003, Dasar Pemrograman Web dengan ASP. Andi, Yogyakarta, Pemrograman WEB Mencakup HTML, CSS, Java Script dan PHP. Andi, Yogyakarta,

Nugroho, Bunafit. 2005, PHP dan My SQL dengan Dreamweaver MX. Andi,Yogyakarta

A,Kristanto. 2007. Analisis dan Desain Sistem Informasi, Yogyakarta, Penerbit Andi.

Zaki, Ali. 2008, 36 menit belajar komputer PHP dan MySQL, Jakarta : PT Elex Media Komputindo,.

Hermawan Dwi Surjono, 2013 membangun Course E-learning Berbasis Moodle edisi kedua, UNY Press

Neni Yuniati, Bambang Eka Purnama, Gesang Kristianto Nugroho, Pembuatan Media Pembelajaran Interaktif Ilmu Pengetahuan Alam Pada Sekolah Dasar Negeri Kroyo 1 Sragen, Jurnal on Computer Scoence - Speed (IJCSS) 12 Vol 9 No 1 Februari 2012, ISSN 1979 - 9330

Ariyanto S. Helianak, Herman Dwi Surjono, Pengembangan e-Learning Mata Pelajaran Teknologi, Jurnal Inovasi Teknologi Pendidikan Volume 1 - Nomor 1, 2014

Edhy Sutanta, Konsep dan Implementasi E-Learning (Studi Kasus Pengembangan E-Learning di SMA N 1 Sentolo Yogyakarta)

Zyainuri dan Eko Marpanaji, Penerapan E-Learning Moodle untuk pembelajaran siswa yang melaksanakan Prakerin, Jurnal Pendidikan Vokasi, Vol 2, Nomor 3, November 2012

Kun Khamidah, Ramadian Agus Triyono, Pengembangan Aplikasi E-Learning Berbasis Web dengan PHP dan
MySql studi Kasus SMPN1 Arjosari, IJNS Volume 2 No 2 - April 2013 ISSN: 2302-5700

Muhdar Abdurahman, Sistem Informasi Jadwal Perkulaiahan Berbasis Mobile pada Politeknik Sains dan Teknologi Wiratama Maluku Utara, IJNS-Indonesia Journal on Networking and Security - Volume 5 No 2 - Mei 2016 - ISSN: 2302 - 5700 (Print) 2354 - 6654 (Online) 